\title{
NEAR AND DISTANT MARVELS: DEFAMILIARISING AND REFAMILIARISING THAUMA
}

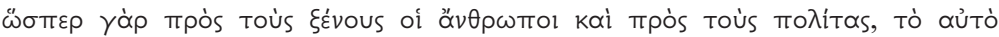

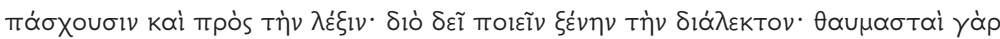

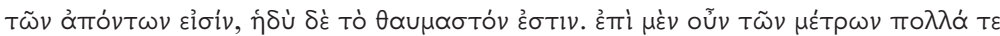

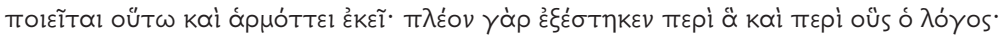

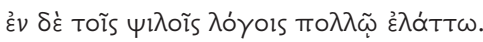

For just as men are affected in a certain way by strangers and in a certain way by their fellow citizens, they are affected in the same way by verbal style. Therefore it is necessary to make language 'strange': for people are wonderers at things which are distant, and the wondrous is pleasurable. In cases of verse, many things produce this effect and it suits that medium: for the things and people found in that discourse are more out of the ordinary. In prose this is true to a much lesser extent.

Aristotle, Rhetoric I404b8-I4

In his discussion of appropriate rhetorical style (lexis) in the third book of the Rhetoric, Aristotle sets forth a claim about the nature of effective rhetorical speech which will go on to reverberate through the subsequent literary critical tradition. He suggests that the task of the effective speaker is to make what is familiar to the listener appear somehow strange, unfamiliar and wondrous again. This claim makes one shift which takes place over the course of the fifth century BCE abundantly clear: thauma is no longer necessarily aroused by an externally visible physical object, event or action, but is now often a response to the effects of language alone. By the time Aristotle composes the Rhetoric in the latter half of the fourth century BCE, the conceptualisation of speech as something able to cause wonder has become concrete. ${ }^{\text {I }}$

I The treatise has been dated to $340-335$ BCE since the latest historical events alluded to in this work fall in this period, though it is likely that Aristotle reworked his ideas about rhetoric over a longer period of time (see Kennedy (I99I) 299-305). 
In the above passage Aristotle uses a simile to explain the effect which he expects successful rhetorical style to provoke. He describes the sense of wonder created when language is 'made strange' as akin to that felt in the presence of a foreigner from far away, a feeling which differs greatly from that experienced in the presence of a fellow citizen. A little further on from this passage Aristotle contemplates how a wonder-inducing strangeness of language might be created by the successful rhetorician. He suggests that one of the primary means of making everyday language 'clear, pleasurable and strange is through the use of metaphor

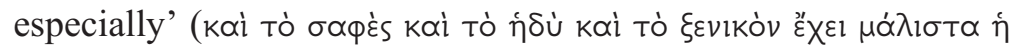

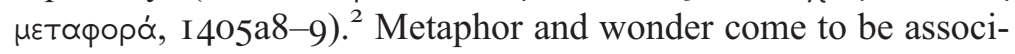
ated together elsewhere in Aristotle's works in a way which exposes a complicated nexus of ideas surrounding the connection between thauma, learning, mimesis and pleasure. We can begin to untangle this web of associations if we turn to an earlier passage in the first book of the Rhetoric (I37Ia3 I-b8): here Aristotle claims that 'both learning and wondering are usually pleasurable, for wondering at something implies a desire to learn, with the result that the object of wonder is an object of desire ... and since learning and wondering are pleasurable, it makes sense that such things, acts of imitation like painting and sculpture and poetry and everything that is well-imitated, are pleasurable, even if the object imitated is not itself pleasurable'. ${ }^{3}$ He posits a similar idea at Poetics I448b4-I7 when he suggests that mimetic objects are pleasurable to contemplate even if the objects they depict are inherently unpleasant. The reason Aristotle gives for this observation is that 'learning is pleasurable, not only for philosophers but

${ }^{2}$ See Moran (I996) 387-9 on the importance of the connection between strangeness and wonder here in light of Aristotle's subsequent argument in the Rhetoric. On the influence of these Aristotelian ideas about the connection between wonder and strangeness in Classical Arabic literary theory, see Harb (2020) 95-7, I I9-22.

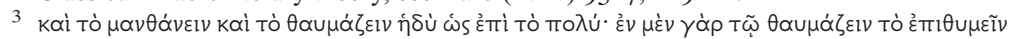

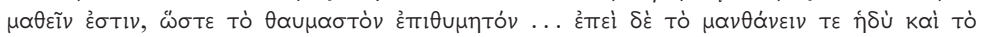

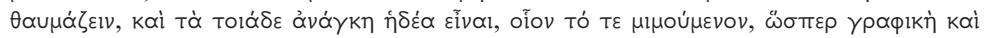

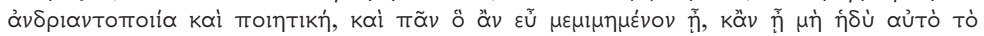
$\mu \varepsilon \mu т \eta \mu \varepsilon \dot{v} о \nu$. For a detailed discussion of the interrelationships between pleasure, learning, wonder and recognition in Aristotle's thought (especially in the Poetics), see Halliwell (I986) 73-8I. Cf. Warren (2014) 67-77 on the connections between learning, pleasure and thauma at Rhet. I37Ia, Poet. I448b and Part. an. 644b. 


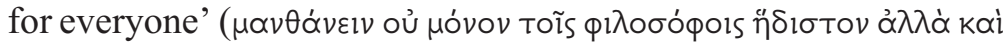

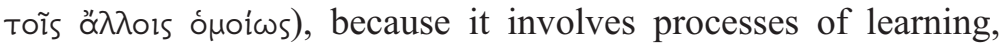
inference and recognition as the viewer 'pieces each thing

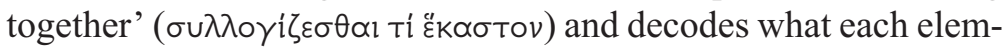
ent of the object viewed (e.g. an image) means.

Later in book 3 of the Rhetoric, Aristotle goes on to claim that metaphor is itself pleasurable precisely because it produces learning, since "naturally learning easily is pleasurable for everyone ... all words that make us learn are pleasant ... and metaphor pro-

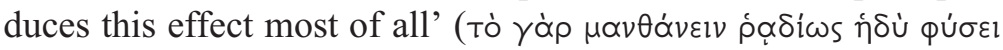

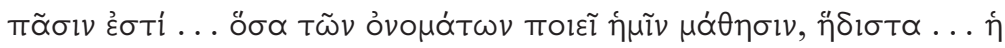

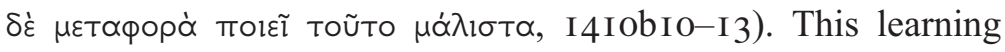
stems from metaphor's ability to elucidate similarities between previously disparate objects which have never been compared in this way before, and its power to encourage the recognition of the familiar within the unfamiliar. ${ }^{4}$ In fact, this is not too dissimilar from the process of recognising similarities and connections which Aristotle considers to be essential to the practice of philosophising in general (Rhetoric I4I2aII-I3): 'it is necessary to make metaphors, as was said earlier, out of things which are related but not obviously so - just as in philosophy too sagacity is required to see what is similar in things far apart' ( $\delta \varepsilon \tilde{\imath} \delta \dot{\varepsilon}$

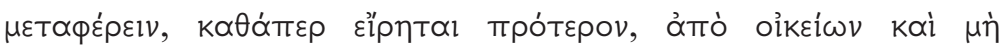

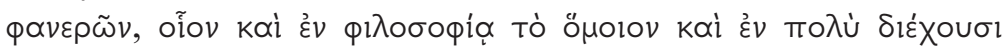

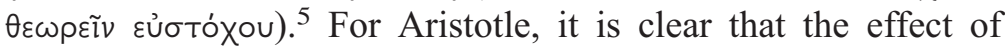
recognising unexpected connections between things which do

4 Aristotle hints at this in his discussion of metaphor at Poetics I459a7, when he states that the ability to discern likenesses between things is something which cannot be taught,

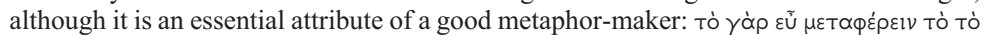

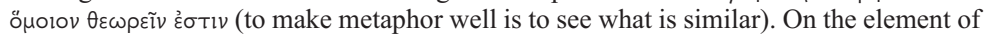
anagnorisis inherent in Aristotle's conception of metaphor, see Swiggers (1984) 44 and O'Rourke (2006) I 58.

5 The interplay between the familiar and unfamiliar, near and far, and the wonder caused by the recognition of potential connections between the two is also implied at the beginning of the Metaphysics (982bI2-I5) when Aristotle notes that wonder is the beginning of philosophy because it encourages us to move on to wondering at greater, more distant matters after first marvelling at the workings of things near at hand. This idea also underlies Aristotle's exhortation (Part. an 644b29-645aI7) to study the nature and bodies of animals and plants before turning towards weightier matters relating to the divine, since we live near at hand among these organisms and can wonder at and therefore learn about them with less difficulty. On these passages, see further Chapter 3, Section 4. Thein (20I4) 2I4-I8 also notes the strong connection between Aristotle's thoughts on 
not normally belong together contributes to creating and sustaining wonder on both aesthetic and philosophical levels. ${ }^{6}$ This wonder then goes on to encourage learning.

These observations concerning the power and potentially wonder-inducing effects of 'making language strange' certainly have a long afterlife in later critical discussions of literary and poetic style. One of the most obvious recapitulations of this idea occurs in the Romantic period, when Coleridge states that Wordsworth's aim in the Lyrical Ballads was 'to give the charm of novelty to things of every day, and to excite a feeling analogous to the supernatural, by awakening the mind's attention from the lethargy of custom, and directing it to the loveliness and the wonders of the world before us'. ${ }^{7}$ But it is within Russian Formalist thought that by far the most influential revisiting of Aristotle's claims about the wonderful power of making language strange are found, with Viktor Shklovsky's concept of 'defamiliarisation' - i.e. the claim that '[t]he technique of art is to make objects unfamiliar' - explicitly based on Aristotle's comments at Rhetoric I404b.

But where do the roots of Aristotle's own idea lie? Was he the first to suggest that language itself can produce wonder and make the familiar unfamiliar, and vice versa? These are the fundamental questions which this chapter will explore, turning first to Aristophanes' Birds and then to Thucydides' History. In both of these works, the ability of language itself to cause its audiences to marvel, and the ease with which words can alter perceptions as a result, are shown to be issues of great importance in Athens, a society which is itself now held up as an object of thauma. In these texts this has a radically dislocating effect, since the rhetoric of wonder which begins to inform Athens' view of its own political and military predominance contributes to distorted

knowledge, learning, pleasure and wonder at Rhet. I404b, I460a, Met. $982 \mathrm{~b}$ and Part. an $644 \mathrm{~b}-45 \mathrm{a}$.

${ }^{6}$ O'Rourke (2006) I7 I-2 aptly summarises Aristotle's conception of wonder as an integral effect of metaphor: 'Vital to metaphor is the contrast between the familiar and the strange, which is the hallmark of wonder ... Metaphor is a continual reminder of the strangeness of things all around: the marvellous in the quotidian ... With its power of estrangement metaphor arrests our habitual relationship with the world. The miracle of metaphor is its power to evoke marvel and astonishment.'

7 Coleridge describes Wordsworth's poetic practice thus in chapter XIV of his Biographia Literaria (I8I7). 
perceptions of the true extent of the imperial might of the city state, leading the Athenians (at least, in Thucydides' view) to overreach themselves. In both of these authors, the unease caused by the sense that thaumata are no longer simply exceptional objects of the natural world or of divine craftsmanship, but are now the result of man-made (often deceptive, and often linguistic) craft, is articulated through continual shifts and reassessments of the relationship between the near and the far, both in literal, spatial terms and in more metaphorical senses. Aristotle's use of an image concerning foreigners and citizens to express processes of linguistic defamiliarisation thus draws upon a deeper and more complex view in this culture of the changing role of language itself - a role which thauma now finds itself an ever more important part of, as the next two chapters will demonstrate. But first, to begin to explore the status of thauma in Athenian society and culture in the last quarter of the fifth century BCE, it is necessary to turn to a work which, on the face of it, has very little to do with Athens as a real-world location at all.

\section{I The Wonder of Nephelococcygia: Aristophanes'Birds and the Edges of the Earth}

In Euripides' Ion, as we saw at the end of the last chapter, birds become ideal signifiers of the confusion between the near and far, the familiar and unfamiliar. At around the same time as Euripides wrote that play, Aristophanes' Birds, performed at the City Dionysia of $4 \mathrm{I} 4 \mathrm{BCE}$, also hits upon the figure of the bird as a means of exploring spatial transgression and its effects. One such effect is the ability to bridge easily the gap between the human and the divine, since birds are capable of crossing not only terrestrial geographical boundaries at will but are even able to move vertically between the mortal realm of earth and the sky, the preserve of the gods. In Birds, the geographical and conceptual transgression linked to these creatures is firmly connected to thauma, as Aristophanes indulges in a humorous form of paraethnography to emphasise, at least initially, just how radically different and distant the fantastic utopian society of Cloudcuckooland supposedly is from the corrupt world of 
contemporary Athens. Towards the end of the play, however, Aristophanes takes advantage of the spatial inversions which the natural movement of birds allows to turn the radically distorting lens of thauma back upon Athenian society itself.

The groundwork for this eventual inversion of 'near' and 'far' is laid from the very opening words of the play. Euelpides' first complaint that the confusion caused by the protagonists' constant

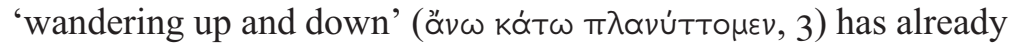
reached the point that he no longer knows where on earth he is

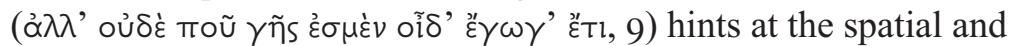
linguistic inversions which are to follow; despite referring to travel over the surface of the earth at this point, the words 'up and down'

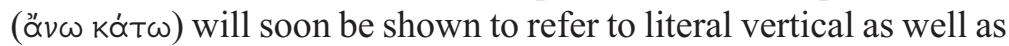
horizontal movement. ${ }^{8}$ The sense of spatial inversion is further reinforced by the gradual realisation that the expected locations of the protagonists' longed-for escape - the wondrous and pleasing edges of the earth - must in their turn be rejected. At the beginning of the play the edges of the earth are initially presented as the expected location of thaumata. Peisetairus' ludicrous claim, when interrogated by Tereus' bird-slave, that he is an unusual 'Libyan bird' $\left(\Lambda_{\imath} \beta u k o ̀ v ~ o ̈ \rho v \varepsilon o v, 65\right)$ seems to hint at Africa as a proverbial location of exotic animals, while Euelpides' claim to be a 'Phasian bird' (Фaбıavıkós, 68) from the opposite side of the world, the region around the Black Sea, reinforces the sense that, initially at least, the world's extremities are to be regarded as the home of the exotic and unusual. ${ }^{9}$ But this assumption quickly breaks down once Tereus' house is finally reached. When asked to use his birdly experience of travel to suggest a location free from Athenian meddling (polypragmosyne), Tereus automatically recommends

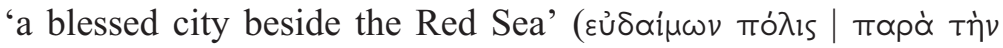

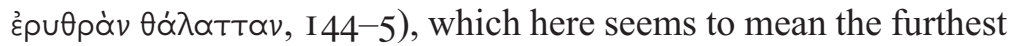
edges of the Persian empire. But this suggestion is immediately

${ }^{8}$ Cf. Rusten (20I3) 3 I4 on the new vertical perspective of space which the play establishes.

9 On Libya as the location of exotic animals, cf. Ronca (I992) I47 and Dunbar (I 995) I56.

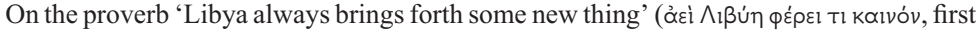
attested in Aristotle's biological works and already described by him as a proverb (paroimia), see Arist. GA $746 \mathrm{~b} 8$ and HA 6o6bI9), see Ronca (I992), Romm (I992) 88-9 and D'Angour (20I I) I09. 
rejected by Euelpides on the basis that Athenian power is able to reach everywhere by sea these days ( $\left.\mathrm{I}_{45^{-}}-8\right)$ - as a result, escape to the marvellous ends of the earth is no longer possible. ${ }^{\text {IO }}$

The sense of spatial collapse between periphery and centre is emphasised still further by the entrance of the chorus, where we find familiar Mediterranean birds flocking together with their more far-flung cousins. Euelpides expresses amazement at the unusual sight, but Peisetairus remains unmoved. Of course, this fits with Euelpides' role as comic buffoon in this play; still, it is notable that Peisetairus never seems to wonder at anything, even going so far as to demand that the birds 'do not fly around

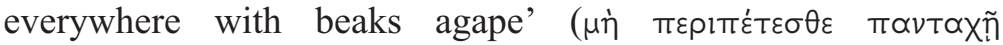

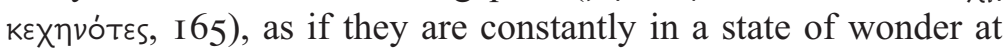
everything. ${ }^{\text {II }}$ Peisetairus' consistent lack of wonder seems to be connected to his increasingly dominant role as the play proceeds. Euelpides, however, seems to reflect the audience's likely reaction to the sight of the comic chorus. His exclamation on the entrance of the Persian Mede bird that 'this bird has an out of place colour'

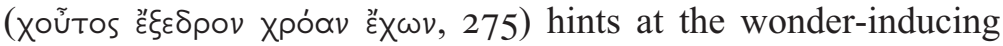
literal and metaphorical dislocations which the play will increasingly delight in as the action goes on, since these words echo a line from Sophocles' Tyro which relates to the literal unusual position of a bird in the sky when a witness asks 'what is this bird in an out

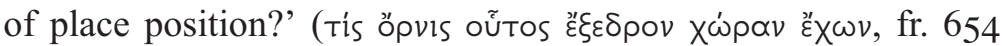
$\operatorname{Tr} G F$ Radt). ${ }^{\text {I2 }}$ Here the Sophoclean sense of religious awe connected with an ill-omened bird has been suddenly displaced and transmuted into an Aristophanic sense of wonder at the exotic, a transformation which renders Euelpides' reuse of the tragedian's expression just as out of place as the bird he is describing.

It seems then that even before Peisetairus' plan begins properly to unfold, the familiar distinctions between the world's centre and

Io For more on Euelpides' comment about the seemingly boundless reach of Athenian imperial power, see Section 3 below. On the apparent impossibility of escape from Athenian imperial power in the Birds, see Amati (2010) 2 I 5 and Bowie (1993) Io6.

II On the birds' wondering response here, see Konstan (I997) 9: 'The gaping mouth is a standard Aristophanic image for dumb wonder'; cf. Arrowsmith (I973) I43, who attributes the fact that the birds are 'agape with wonder and desire' to their zeal for 'the unknown frontiers of boundless conquest'.

I2 See Dunbar (I995) 232 and Sommerstein (I987) 2 I4. 
its peripheries have already started to crumble, and the process of playing with the familiar and unfamiliar has already begun. This is reinforced by the strong Herodotean echoes that surround the most important structural aspect of Nephelococcygia: the city wall. ${ }^{\mathrm{I3}}$ At 550-2, Herodotus is recalled when Peisetairus instructs the birds to build a wall around the city out of baked bricks:

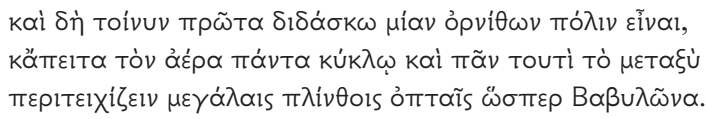

Well then, I instruct this first of all: make a single city of birds, and then surround all of the air and everything which lies between heaven and earth in a circle with big kiln-baked bricks just like Babylon.

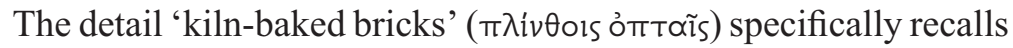
Herodotus' description of the construction of Babylon's massive external wall, a structure similarly made out of 'bricks baked in

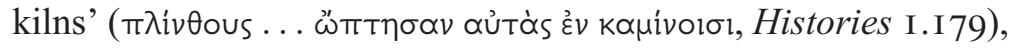
making clear that the historian's account of one of the proverbial seven wonders of the world is what Peisetairus has in mind for Nephelococcygia here. ${ }^{\mathrm{I} 4}$ The wondrous nature of the Herodotean wall is made even clearer by the messenger speech narrating its construction. The messenger begins by emphasising the structure's tremendous dimensions ( I I 25-9):

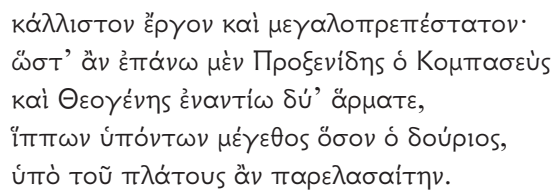

${ }^{13}$ On the general importance of the wall as a boundary marker and the spatial ramifications this has in the play, see Kosak (2006) I73-80. I am grateful to one of the anonymous readers for drawing my attention to the fact that in addition to the wall the geometry and organisation of the city as a whole can be considered a source of potential thauma, especially since the proposed regular organisation of the city contrasts with the comparatively unruly natural development of real cities. On conceptions of various schemes of ordered spatial organisation in Nephelococcygia, see Amati (2010) 2 I3-27.

${ }^{14}$ See Dunbar (I995) 374 and Sommerstein (I987) 233 on the Herodotean echo. Fornara (I97I) 28-9 argues (rightly) that this is a rare specific verbal parody of a particular Herodotean passage, rather than just a vague allusion to the historian's style. See also Nesselrath (2014) 58-60 on the possibility that Aristophanes had access to a written edition of Herodotus' Histories. 
A most fine and most magnificent work, so wide on top that Proxenides of Boasttown and Theogenes could drive two chariots past each other with horses as big as the Wooden Horse [i.e. the Trojan Horse] attached to them.

Here we are immediately thrust into the Herodotean rhetoric of

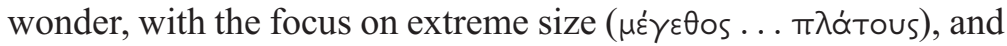
the labelling of the structure as a 'most fine and most magnificent

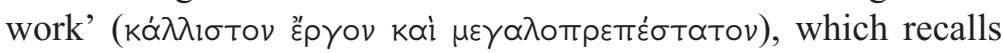
the proem of the Histories and its stated claim of keeping alive

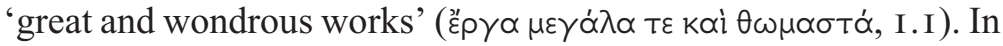
fact, the messenger even once again makes explicit reference to Herodotus' description of Babylon's wall at Histories I.I 78-9 by claiming that the birds' structure allows two chariots to be driven around the top of the wall by Proxenides and Theogenes (apparently a pair of well-known braggarts); in Herodotus' version the fact that space was left on top of Babylon's wall 'for the driving around of one four-horse chariot' ( $\tau \varepsilon \theta$ pi $\pi \pi \omega ~ \pi \varepsilon \rho \varepsilon^{\prime} \lambda \alpha \sigma l v$, I.I 79) is a prime cause of the overwhelming magnitude and thauma of the wall's construction as a whole. ${ }^{\text {I5 }}$

Furthermore, the description which the messenger then gives of thirty thousand cranes from Libya and ten thousand storks helping to build the wall only increases the sense that Herodotus' focus on measurement, scale, large numbers and supposed extreme accuracy is being parodied here (I I3O-4I):

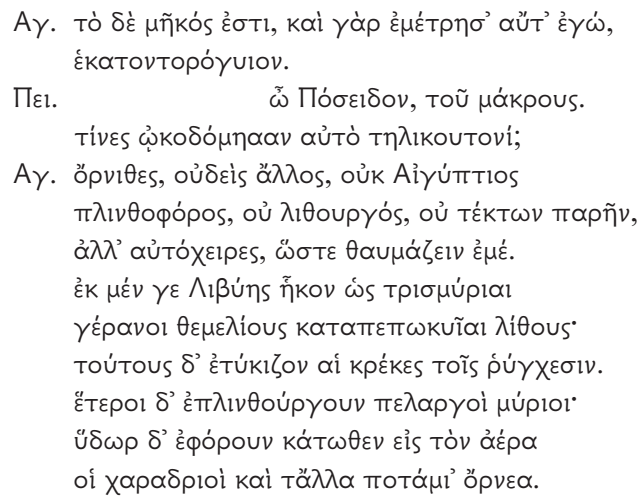

15 See Dunbar (1995) 595 on this instance of Aristophanes' intensely allusive Herodotean language. 
6. I Aristophanes' Birds and the Edges of the Earth

Messenger: And the height - for I measured it myself - is a hundred fathoms.

Peisetairus: O Poseidon! That's high! Which people built this to such a height?

Messenger: Birds, and no one else: no Egyptian brick-bearer, no stonemason, no carpenter was present; instead they built it with their own hands, with the result that I marvel. From Libya thirty thousand cranes who had gulped down foundation stones arrived, and the corncrakes were working them with their beaks. Another ten thousand storks were making bricks, and the curlews and the other river birds were bringing water up to the sky.

Again, Aristophanes has picked up on Herodotus' penchant for detailing large measurements when designating a distant manmade object as something to be marvelled at. ${ }^{16}$ The messenger's asides concerning his own response to witnessing the marvel of the wall also manipulate the stance of the Herodotean narrator in a new and humorous way, first through the use of a Herodoteanstyle autoptic verification of detail in the aside that the height of the wall is one hundred fathoms, then by the announcement that the effect on the eyewitness of the wall and its construction was one of wonder. ${ }^{17}$

These humorous references to the importance of autoptic accounts of distant marvels are not the only instances in which Herodotean-style rhetoric of ethnographic thauma is exposed to ridicule in the Birds. Aristophanes again takes a swipe at ethnographic descriptions of thaumata when Tereus warns his fellow birds that they are about to hear plans about the wall from Peisetairus which are completely 'unbelievable and beyond listen-

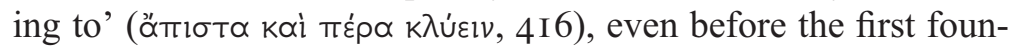
dations of the marvellous wall of Nephelococcygia are laid. From the very moment of its initial conception, the wondrous nature of

${ }^{16}$ On Herodotus' frequent recourse to large numbers and the language of measurement to describe the magnitude of thomata in the Histories, see Hartog (I988) 230-7, Welser (2009) 375 and Priestley (2014) 57.

${ }_{17}$ On the Herodotean phraseology here, see Sommerstein (I987) 274-5 and Dunbar (I995) 596-9. 
Nephelococcygia is constantly undercut, even by Peisetairus himself, as a sense of scepticism regarding the very believability of any object labelled as a marvel gradually arises. This becomes clearest when the chorus' exhortation to wonder at the speed with which the fortifications were erected is quickly taken up by Nephelococcygia's founder, who equates the fact that the wall is worthy of wonder with its utterly fictitious nature ( I I64-7):

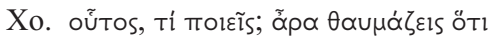

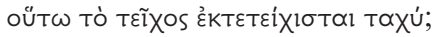

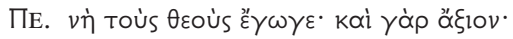

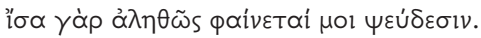

Chorus: $\quad$ You there, what are you doing? Are you astonished that the wall has been built up so swiftly?

Peisetairus: I am indeed, by the gods: because it's worthy of astonishment. For truly it seems to me to be equal to lies.

Peisetairus' words here provide a concrete hint that the marvellous wall which is being described may in fact be marvellous not because of its size, but because of the fact that it does not exist at all: this is a structure created purely with words, a discursive wall which comes into being, when required, through language itself. This interpretation becomes more likely when the structure's seeming defensive purpose is undercut almost as soon as it has been completed, during a scene (I I99-224) in which the messenger Iris does not even notice the wall's existence, passing through it completely unhindered and ending up confused by Peisetairus' insistence that she has transgressed this new boundary. $^{\text {I }} 8$

Through these consistent parodic references to Herodotean thauma during the scenes of the new city's construction, Aristophanes deliberately aligns this novel society of birds and metamorphosed humans with those of fantastic peoples situated at the edges of the earth in Greek thought. Seeing as Peisetairus' new city is supposedly located at a distant geographical boundary in the sky, in one sense Aristophanes' use of unusual and often

\footnotetext{
${ }^{18}$ See Amati (20I0) 2I7, Kosak (2006) I75 and Sommerstein (I987) 4 on Iris' complete ignorance of the supposedly insurmountable wall's presence in this scene.
} 
far-fetched reports of marvels which may be encountered in reports of lands distant from Greece is fitting, and it is easy to create humour through the simple inversion of usual notions of centre and periphery: the edges of the known world now stretch upwards on a vertical axis, rather than simply expanding out on a horizontal axis from the Hellenic centre. At the same time, however, the injection of ethnographic thauma into his play's construction of a supposedly novel society allows Aristophanes to critique the general believability of objects designated as thaumata, and the reliability of the ethnographic tradition as a whole. This becomes an increasingly pressing issue as the play draws on and the audience is gradually refamiliarised with the greatest thauma of all: Athens.

\subsection{Familiar Thaumata: The Bird-Chorus' Wondrous Travels}

In the final scenes of the Birds it becomes clear that it is not really Nephelococcygia with its wondrous wall which is truly deserving of thauma, but rather the city of Athens itself. Aristophanes transfigures Athens into an object of wonder through the repeated transformation of metaphor and other familiar figures of speech into unexpected and often troubling literalisations as the play draws on. ${ }^{\text {I9 }}$ This becomes most evident in the play's final scenes as the bird-chorus perform a song describing the thaumata they have seen on their travels over Peisetairus' new sphere of influence. The song's stanzas, despite being non-consecutive (I470-8I; I 482-93; I 553-64; I694-I705), are nevertheless clearly connected structurally, thematically and metrically. ${ }^{20}$

Within this song about seemingly distant thaumata Aristophanes combines two main generic influences. The first is the ethnographic periodos ges, which systematically describes the route and geographical features of a (distant)

19 On the importance of verbal artifice and the literalisation of metaphor in the Birds, see especially Dobrov (I997) 95-I32; cf. Sommerstein (I987) 3, Bowie (I993) I73, Slater (I997) 85-6 and Rothwell (2007) I75.

${ }^{20}$ See Parker (I997) 346-50 on the metrical correspondence of these four stanzas, which she terms 'lampoon-songs', and their use as a means of marking out the dramatic structure of the play's end. Cf. Moulton (I98I) 32, 45-6, Dunbar (I995) 688 and Rusten (20I3) 298 on the structure and thematic unity of the song as a whole. 
journey. ${ }^{2 \mathrm{I}}$ The second, of course more common in Aristophanic comedy, is tragedy. In particular, in this specific choral song Aristophanes parodies the tendency of certain Euripidean choruses to sing of how they wish to become birds so that they can flee from whatever troubles are unfolding in front of them. ${ }^{22}$ The contrast drawn in these odes between the unpalatable situation faced by the chorus in their present location, and the potentially happier life to be found in far-off places towards the edges of the earth is something Aristophanes repeatedly picks up on and reinvents in the Birds in order to critique the norms of contemporary Athenian society.

The most pertinent extant example we possess of the type of imagery which Aristophanes is parodying is found in the second stasimon of Euripides' Hippolytus, first performed in $428 \mathrm{BCE}$, long before the first performance of Birds in 4I4. After the shocking revelation that Phaedra has hit upon death as a remedy for her shame (7I5-3I), the geographical scope of Euripides' play is radically expanded in this ode as the chorus react with an anguished wish for a sudden avian transformation $(732-4)$ :

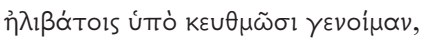

iv $\alpha \mu \varepsilon \pi \tau \varepsilon \rho \circ \tilde{\sigma} \sigma \sigma \alpha \nu$ öp-

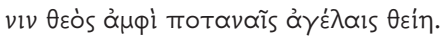

If only I were in the steep mountain clefts, where a god might make me into a winged bird among the flying flocks.

The chorus go on to emphasise their longing for escape by imagining themselves soaring away from their distressing situation in Troezen, and winging their way instead towards the world's very western edges. The geographical movement of the ode tends increasingly towards the fantastic, as the chorus first envisage

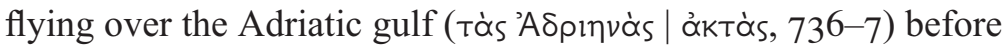

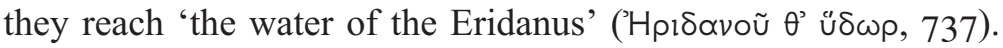
The river Eridanus, the location of Phaethon's fiery chariot crash, was thought to be located towards the westernmost edge of the

${ }^{21}$ See Rusten (2013) 308.

22 On Euripidean 'escape odes' and their tendency to evoke distant places, see Padel (I974), especially pp. 228-3I on bird imagery; cf. Swift (2009) 364 on the Euripidean choral 'escape fantasy'. 
world, flowing into the outermost sea on the western side of Europe. ${ }^{23}$ But the chorus' fantastic journey does not stop there: their distress is such that only the garden of the Hesperides, near the Pillars of Heracles, the western end point of the world - or the

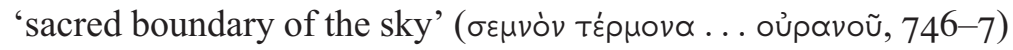
as the chorus term it - seems to offer a potential haven from the horror of Phaedra's shocking revelations.

As might be expected, in the later so-called 'escape-plays' this Euripidean imagery is transformed in line with the surprising geographical inversions common in those works. Since these plays are set in locations near the edges of the earth, it is Hellas itself which becomes an idealised distant space which the chorus longs to escape to, as we see in the second stasimon of the IT (I089-I52). After learning that Iphigenia has gained the opportunity to break free from her current plight and return home, the chorus long to escape captivity in the Taurian land and similarly return to Hellas and their maiden choral dances. The first strophe, a single lyrical period, is framed by bird imagery as the desire to flee away is outlined (I089-IO5):

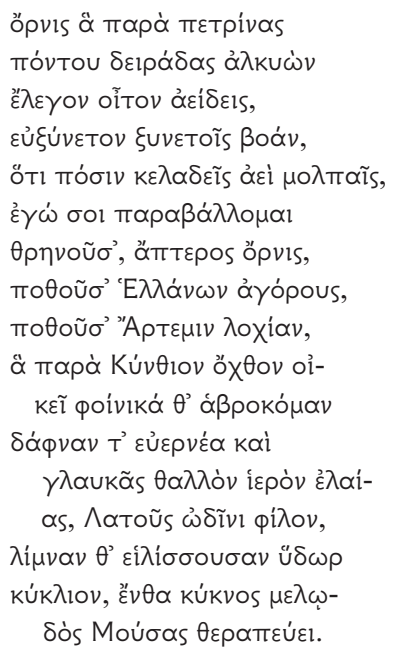

23 The actual location of the Eridanus was a matter of debate in antiquity: for example, in his discussion of the earth's edges Herodotus famously (Histories 3.I I 5) dismisses the geographical veracity of the claim that the Eridanus actually exists and issues forth into the sea on the westernmost edges of Europe. On ancient ideas about the river's location see Barrett (I964) 300-I. 
Halcyon bird, you who sing lamenting your fate, beside the rocky ridges of the sea, a cry well-understood by those who understand that you loudly mourn your husband ceaselessly with songs like mine - I, a wingless bird, compete with you in wailing, longing for the meeting places of the Hellenes, longing for Artemis of childbirth, who lives beside the Cynthian hill and the delicate-leaved palm and the flourishing laurel and the sacred shoot of the grey olive, dear to the birth-pains of Leto, and the lake which swirls its water in a circle, where the tuneful swan serves the Muses.

The chorus begin by comparing their lamentation with that of the halcyon, whose humanlike cry of mourning is explained by the myth that she is the metamorphosed form of Alcyone, who bewails her dead husband Ceyx. The distant land which the chorus particularly longs for is the centre of the Athenian empire, Delos, home to Apollo and Artemis. There they might resume their native worship of a Delian Artemis who is much less bloodthirsty than the Taurian goddess in whose cult practices the women are currently forced to participate. Specific markers of the landscape in Delos which relate to Greek cult practices there are picked out as objects of the women's particular longing: the palm associated with the birth of Apollo and Artemis, the laurel sacred to Apollo, and the olive tree. The olive appears for the first time in our extant texts in connection with Delos here; as Athens' sacred tree, undoubtedly it reminds the audience of current Athenian influence over the island. ${ }^{24}$ The long lyrical sentence ends with the appearance of another bird: this time a species associated with Apollo rather than Artemis, the tuneful swan.

In their opening address to the halcyon/Alcyone, the chorus bemoan the fact that they currently resemble a 'wingless bird'

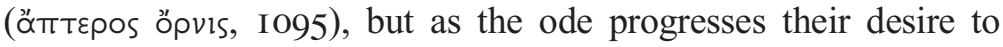
overcome this difference becomes clear. This culminates in another explicit wish to undergo an avian metamorphosis ( I I38-42):

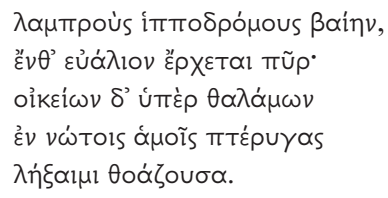

${ }^{24}$ On the intrusion of the olive tree into the traditional Delian scene as a marker of Athenian influence, see Cropp (2000) 240, Kyriakou (2006) 355 and Hall (2012) 55. 
If only I could travel along the bright chariot-tracks where the fire of the fine sun goes! But I would cease the quick movement of the wings of my back above the rooms of my home.

In fact, these choral addresses to birds seem to have been a technique which Euripides particularly favoured: another example can be found in the first stasimon of Helen, where the chorus 'cry out' to the melodious 'tearful nightingale'

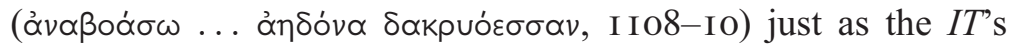
chorus call out to the halcyon bird. ${ }^{25}$

Aristophanes makes fun of Euripides for this tendency most explicitly in the Frogs (405 BCE) by portraying Aeschylus mocking Euripidean choral lyric with a song which opens with an address to halcyons (I309-I2):

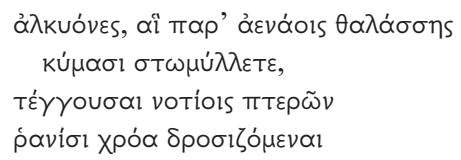

O halcyons, who chatter beside the ever-flowing waves of the sea, moistening and besprinkling the skin of your wings with rainy drops!

On a much larger scale Aristophanes parodies the tragic avian wishes of these Euripidean choruses in the Birds as well. For example, just before the bird-chorus begin their song about distant thaumata Peisetairus' new city is approached by a succession of unpalatable Athenians (a father-beater at I337-7I, Cinesias the dithyrambic poet at I372-409 and a sycophant at I4IO-69), all of whom desperately long for a pair of wings to enable them to escape Athens and enjoy the riches of the new utopia in the sky. The approach of the sycophant, the final Athenian longing for wings, is immediately followed by Aristophanes' own take on tragic choral bird imagery: a chorus of actual birds singing about

25 Euripides also turned to the conceit of inverting the conventional wish to flee away from danger towards the world's peripheries in Helen. There the chorus sing of Helen and Menelaus' prospective return to Sparta, and add their own wish to flee from Egypt by becoming birds (I478-9). More specifically, they long to join migrating cranes as they fly over the known world, fleeing from the wintry weather of the north and heading toward Libya in the far south (I479-82), passing over Sparta and bringing news of Menelaus' homecoming (I49I-4). On the significance of this bird imagery, see Steiner (2OII) 3IO-I5. 
the fantastic lands and thaumata they have overflown. Aristophanes thus reifies the familiar lyrical wish of this type of Euripidean chorus, metamorphosing the figurative language of tragic lyric into a comedic spectacle, as the actors literally don wings in front of the audience. ${ }^{26}$

This paratragic take on Euripidean choral lyric is exuberantly fused with a parodic rewriting of Herodotean-style ethnography, as the first two stanzas of the Birds' travel narrative demonstrate (I470-93):

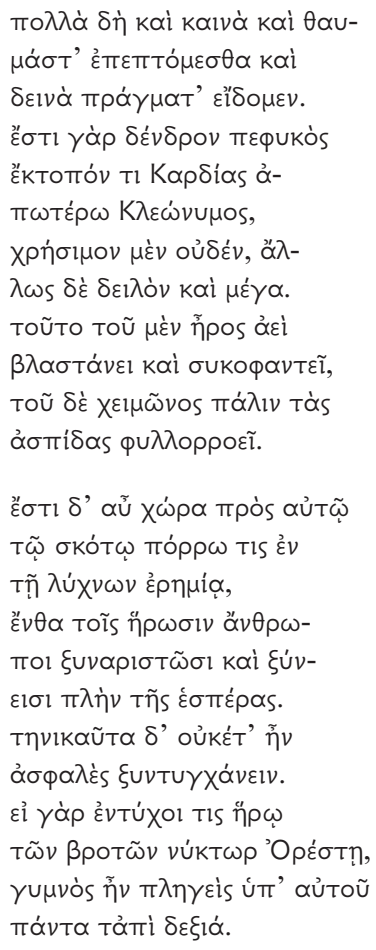

Many things both new and wondrous have we flown over and strange acts have we seen. For there is a certain extraordinary tree that grows somewhat far away from Heart-ford, ${ }^{27}$ called Kleonymos - useful for nothing, but in other respects

${ }^{26}$ See Dobrov (I997) IOO and II7 on how the literalisation of the "would that I were a bird!' topos of Euripidean choral lyric is a central underpinning of the Birds' plot.

27 A pun suggested by Sommerstein (I987) 295 which aptly captures the double meaning of the Greek wordplay. 
cowardly and big. In spring this tree always buds and blooms with vexatious litigation (lit. 'shows forth figs'), while in wintertime it sheds its shields like leaves.

There is a land far off at the edge of darkness, in a lampless wasteland, where men have lunch and meet with heroes - but not in the evening. At that time it's no longer safe to meet together. For if any mortal met with the hero Orestes by night, he would be stripped naked and paralysed all down his right side.

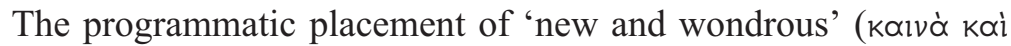
$\theta \alpha u \mu \alpha$ ó ') at the beginning of the song sets up an expectation that we are about to hear a catalogue of distant ethnographic thaumata. But it soon becomes obvious that Aristophanes has something different in mind, as exotic thaumata from unfamiliar lands are substituted with the defamiliarised practices, people and objects of quotidian Athenian life. The first real thauma is the so-called Kleonymos tree - but rather than the expected botanical marvel, the punning on Kardia as both a place name (referring to a colony in the Thracian Chersonese) and as a simple noun ('heart', 'courage') soon lets us recognise that what is really being described is less a wondrous tree than a cowardly Athenian citizen. The bizarre imagery created through the transposition of man and plant in this first description of the wondrous Kleonymos tree (e.g. the use of

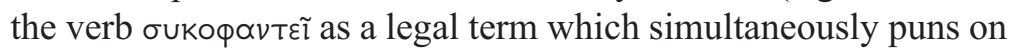
the word's etymological relationship with the word 'fig') is one way in which the familiar meanings of words are shed, and unfamiliar nuances unexpectedly taken up.

The antistrophe continues to play on the conventional imagery of the earth's edges by purporting to describe a land so distant that it lies at the edge of darkness itself. This dark land is reminiscent of the scene of Homer's Nekyia in the Odyssey: the territory of the Cimmerians, a distant people imagined as living in the north, situated by Homer (Od. II.I3-I5) near the far-off boundary of the world formed by Ocean in a place which is gripped by perpetual night because of the sun's absence (Od. I I.I 5-I9). ${ }^{28}$ At first glance, it seems that Aristophanes is describing a typical distant and wondrous semi-mythical locale in which gods and men are close and able to dine together, just as the gods are described as

${ }^{28}$ See Dunbar (I995) 69I for further references to the earth's sunless northern edges in Greek literature. 
sharing feasts with the Phaeacians at Odyssey 7.203. He goes on to suggest that mythical heroes, such as Orestes, might also lurk in such far-off places, perhaps referring here to the Greek conceptualisation of distant islands (such as the Isles of the Blessed) as fitting locations for deceased heroes. ${ }^{29}$ It soon becomes clear, however, that this is not really a description of the sunless extremities of the earth but rather a description of the dangers of wandering around Athens at night: Orestes is not a mythical hero, but a common thief liable to strip the unwary of their clothes. ${ }^{30}$

Aristophanes continues to build on this unflattering vision of Athens through the lens of ethnographic thauma in the third stanza of the bird-chorus' song as a pseudo-ethnographic tone combines with play on the literal and metaphorical meanings of words (I553-64):

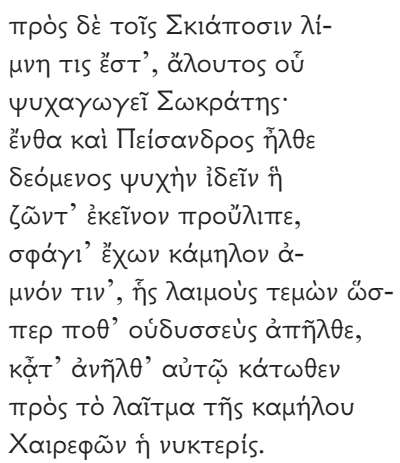

And near the Shadowfeet there is a certain swamp, where Socrates - never bathing raises dead spirits. And there Peisander went asking to see the soul which had abandoned him while he was still alive. He had a baby camel as a sacrificial offering; after cutting its throat, just like Odysseus did, he stepped back, and up to him from below, attracted to the deep pool of camel's blood, came Chaerephon the bat.

The description of Socrates raising ghosts as the chief marvel of the land of the Shadowfeet is humorous not only due to the

29 See Rusten (2013) 309-Io for the suggestion that this stanza refers to distant islands as fitting locations for heroes such as the mythical Orestes.

$3^{30}$ Orestes seems to have been the name or nickname of a notorious cloak thief in Athens: the chorus have already complained of his thieving exploits in line 7I2; cf. Euelpides' complaint about being mugged and stripped of his cloak after being clubbed over the head at night in lines $492-8$. 
ludicrousness of the image in itself, but also because it plays with the literal and metaphorical meanings of the verb for 'soulleading' or 'spirit-raising' ( $\psi \cup \chi \propto \gamma \omega \gamma \varepsilon \tilde{\imath})$. Here the term refers to Socrates' actual ghost-raising, at the same time as it reminds us of its growing use as a term referring to the beguiling and seductive nature of rhetoric itself. ${ }^{3 \mathrm{I}}$ This sense that rhetorical language is increasingly bound up with the effect of thauma becomes even more obvious in the final stanza (I694-705):

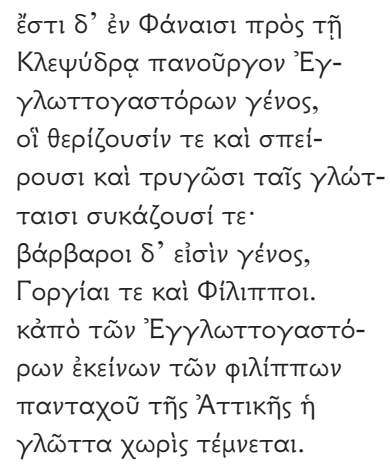

In Denunciation-land, near the Waterclock, there are the tricky Tongue-Belly people, who reap and sow and gather in vintages with their tongues - and they unscrupulously prosecute with them too. They are a barbarian people, Gorgiases and Philippuses. And after the fashion of these Philippic Tongue-Belly people everywhere in Attica the tongue is cut out separately.

Wordplay again stretches familiar lexical meanings into unfamil-

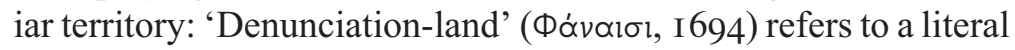
harbour on Chios while hinting at the verb paiveı, which in this case means 'to inform against someone' and is supposed once again to bring the practice of sycophancy to mind; 'Waterclock'

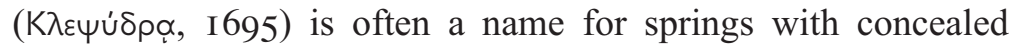
sources (one such was at the foot of the Acropolis), as well as referring to the clock used to time speeches in the law courts. ${ }^{32}$ The 'Tongue-Belly people' are not an exotic, distant tribe, but orators in Athens who live and fill their bellies as a result of words,

${ }^{31}$ On the play with the meaning of $\psi v x \alpha \gamma \omega \gamma$ हा, see Dunbar (I995) 7I I-I 2 and Moulton (I98I) 40 .

${ }^{32}$ For the wordplay in this stanza, see Hubbard (I997) 3I and Dunbar (I995) 740-4. 
the product of their tongues. These people are said to be 'barbarians', a charge which contemptuously hints at the famous rhetorician Gorgias' non-Athenian, Sicilian origins, while at the same time maintaining the ethnographic tone of this description of everyday Athenian life. It is not known for certain who Philippus might be, though clearly he is another Gorgianic orator. ${ }^{33}$ Aristophanes completes this fantastic vision with another reference to the overwhelming importance of both literal and metaphorical tongues in Athens, focusing on the separate cutting-out of the tongue from the sacrificial animal, an Athenian religious custom familiar from everyday life which sounds plausibly exotic when defamiliarised and presented with a bizarre origin (aition) through the ethnographer's lens, while simultaneously offering yet another coded insult against the power of rhetoricians' tongues in the Attic lawcourts.

As we can see, as the Birds draws to a close and the final scenes reveal that this is a play about Athens after all, despite the opening claims to the contrary, there is one aspect of Athenian society in particular which is presented as the ultimate thauma: the use and abuse of language itself. By approaching everyday Athenian life with the eye of an ethnographer hungry for thaumata, Aristophanes manages to defamiliarise the audience's well-known surroundings, simultaneously encouraging renewed assessments of Athens, her imperial ambitions, their causes, and their potentially dislocating effects. In the play's final choral songs, the focus on thauma in unexpected contexts continues to draw attention to the place of wonder in ethnographic accounts, but there is perhaps also a concomitant and increasing sense that comedy as a genre can itself be framed as a sort of ethnography of Aristophanes' own society.

\subsection{The Wonder of Athens: Thucydides and Thauma}

This redefinition of thauma as a concept which can now be associated primarily with one's own society is a key effect of the

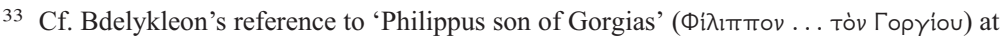
Arist. Vesp. 42 I: it is not clear if Philippus was literally a son of Gorgias or, more likely, his student. See Dunbar (I995) 743 for a detailed discussion of Philippus' possible identity. 
process of linguistic defamiliarisation and refamiliarisation which the Birds presents to its audience. For Aristophanes, this redefinition of the potential boundaries and meaning of wonder is strongly connected to Athens' imperialistic drive, with the fantastic colonisation of the marvellous expanses of the sky presented as the final frontier of Athenian dominance. The real-world engagement of the Athenians in ambitious political and military activity at the time of the Birds' first performance in $4 \mathrm{I} 4 \mathrm{BCE}$ lends an additional power to Aristophanes' focus on the ambivalent nature of Peisetairus' colonisation of the sky. In the summer of 4I 5 the Athenians set out on an expedition against Sicily, which aimed both at quashing Syracusan influence and establishing Athenian control over the island as a whole. Aristophanes clearly makes reference to the contemporary situation in Sicily at three points within the play, all of which relate to the generals in command of the expedition. At I45-7, Alcibiades' recall to Athens on charges relating to the mutilation of the Herms is hinted at when Euelpides rejects the suggestion of fleeing to the shore of the Red Sea on the basis that the Salaminia, the sacred state trireme which was sent to arrest and retrieve Alcibiades, might appear there and haul him off too. The role of Nicias in contemporary politics is also referred to twice: first when Euelpides tells Peisetairus that 'in terms of clever

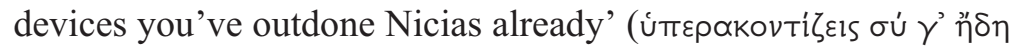

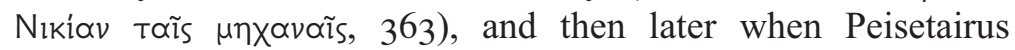
declares that his plan should be put into action at once since there is 'no time for faffing about like Nicias' ( $\omega \rho \alpha$ ' $\sigma \tau i v$ oủ $\delta \dot{\varepsilon} \mu \varepsilon \lambda \lambda$ ovıкı $\tilde{\alpha}, 639)$ - an obvious reference to the older statesman's reluctance to sail against Syracuse.

It is important to stress, however, that the eventual disastrous outcome of the expedition would not yet have been apparent to the Birds' original audience. ${ }^{34}$ The overall outcome of the enterprise still hung in the balance at the moment of the play's writing and first production, but that is not to say that contemporary debate

34 See e.g. Pelling (2000b) I26, Asper (2005) 6-I 8 on contemporary attitudes towards the expedition at the moment of the Birds' production; cf. Dunbar (I995) 2-4 on Birds and the contemporary political situation regarding Sicily. For a more sceptical approach about the significance of Sicily see now Hall (2020) I87-2I3, which draws out the importance of Athens' relationship with Thrace and its influence on the play. 
over the nature and role of Athenian imperialism in relation to Sicily is not in the background of Aristophanes' vision of Peisetairus' quest to colonise the sky. Certainly, the connection between conquest, imperial expansion and thauma, and the potential lure of the acquisition and control of objects which can be labelled as thaumata, seems to form one strand of contemporary discourse concerning Athenian imperial power which the Birds picks up on. The importance of thauma becomes apparent when we compare Aristophanes' conceptualisation of the newly marvellous nature of Athens during the Sicilian expedition with Thucydides' retrospective vision of the power and effects of wonder in relation to Athens and Athenian self-fashioning during the Peloponnesian War.

Thucydides' view of the place of wonder in Athenian society during this period is, of course, complicated by the importance the concept of thauma had assumed in the ethnographic and historiographical tradition. There is undeniably a relative paucity of words relating to wonder and astonishment in Thucydides' work compared to the frequency of such terms in Herodotus' Histories. When thaumata in the History are examined in detail, it soon becomes clear that very different types of objects are labelled as marvels in this work in comparison to Herodotus' writing, and that the concept of thauma is itself now configured in transformed terms. It is certainly not the case, however, that Thucydides' interest in wonder functions as a means of subtly maligning Herodotus' work, or that thauma has become an unimportant concept and force in Thucydides' historiographic vision. ${ }^{35}$ Instead, the relative infrequency of thaumatic language in Thucydides' History only renders its occasional appearances more striking.

The significance of wonder to Thucydides' narrative becomes clearest when the appearances of thauma and ekplexis within the narrative of the expedition to Sicily in books 6 and 7 are analysed.

35 See Priestley (20I4) 6I-8 on how a divergent attitude towards thauma is one of the ways in which Thucydides differentiates himself from Herodotean historiography. Cf. Scanlon (1994) I65-7I, who reads Thucydides' references to thauma as examples of direct engagement with, and even verbal allusions to, Herodotus' Histories. On the relative paucity of thauma and cognate terms in Thucydides, see also Mette (I960) 67-8. 
Just as thauma assumes an important place in Peisetairus' founding of a city in the sky, which is portrayed as an imperialistic colonisation, so too does wonder play a key role in the portrayal of Athenian motivation for the Sicilian expedition, a voyage which is framed by Thucydides as a similar sort of colonising venture. ${ }^{36}$ The potential for wonder is emphasised by the fact that the Athenians are presented as almost entirely ignorant of the reality of the situation in the west before they set out on their expedition. They believe that Sicily is a far-off, mysterious land which sustains a society radically different from their own. At the very beginning of book 6, Thucydides stresses that 'most of the Athenians were unfamiliar with the size of the island and the number of its inhabitants, both Greek and barbarian, and unaware that they were undertaking a war which was not much inferior to the one which they were waging against the Peloponnesians'

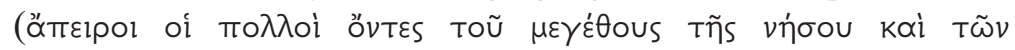

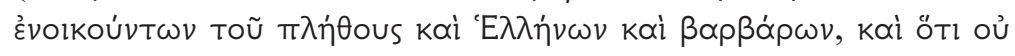

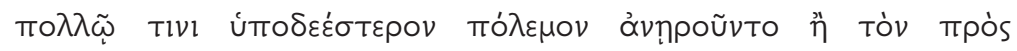

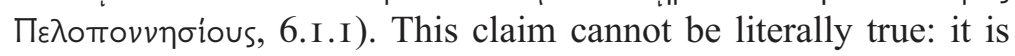
clear that contact between Athens, Sicily and Italy more broadly had been significant and sustained throughout the fifth century long before 4I5 BCE: for example, a large contingent of Athenians had visited the island already in $426 .{ }^{37}$ This apparent ignorance of the west takes on a wider metaphorical significance over the course of books 6 and 7, as it becomes increasingly clear that the Athenians are just as unfamiliar with the true extent of their own power as they are of the true nature of the Syracusans. The geographical inversion of the customary location of thaumata is part of this distorting process: Athens itself is now more marvellous than the seemingly distant land of Sicily - though Thucydides soon shows that the Syracusans are more similar to the Athenians than the latter could ever have imagined. By mapping the way in which thauma intersects with this constant

${ }^{36}$ See Green (I970) I3I, Avery (I973) 8-I3 (who draws explicit parallels between the colonisation theme in Birds and Thucydides) and Kallet (200I) 25 on Thucydides' presentation of the Sicilian expedition as a colonising venture.

37 For the strict factual impossibility of Thucydides' opening claim, see D. G. Smith (2004) 33-70, Hornblower (2002) 4I-3, I63 and (2008) 5-I2, 260. 
inversion of the concepts of the near and far, the familiar and unfamiliar, Thucydides' conception of the radically distorting and dangerous effects that ensue when people's capacity for wonder is manipulated becomes apparent. It is this new conception of thauma which becomes predominant in the fourth century BCE, as wonder's ability to connect self and other through potentially distorting processes of (verbal and/or visual) representations seemingly becomes a matter of increasing interest and anxiety.

But before we can understand the role which thauma plays in the historian's vision of the origins and eventual failure of the Sicilian expedition, it is necessary to examine the other most notable passage in which Thucydidean thauma plays a vital role: Pericles' Funeral Oration. For it is here, during Pericles' famous speech in book 2, that we see thauma most transparently associated with Athenian society itself for the very first time. ${ }^{38}$ Whereas Aristophanes' Birds presents us with the prospect of Athens as the ultimate thauma more obliquely, as the paradoxical punchline of a joke, Pericles is unequivocal in his vision of Athens' ability to induce wonder in all who witness or contemplate the polis and her power (2.4I.3-4):

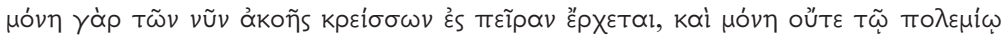

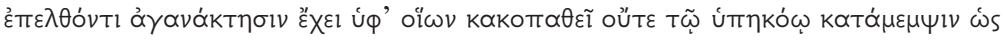

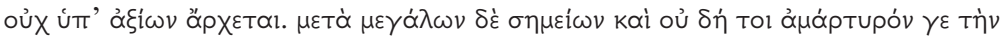

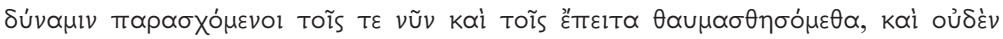

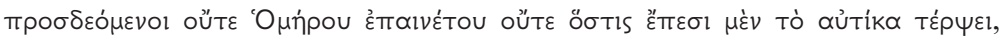
$\tau \tilde{\omega} \nu$ ' '

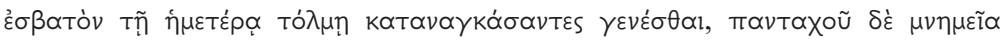

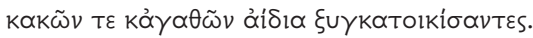

For Athens alone of cities today is even greater, when put to the test, than reports suggest, and it is Athens alone which no enemy who comes up against her feels angry about when he suffers defeat, and none of her subjects resent her, thinking they are ruled by those who are unworthy. And with mighty monuments, and because of the power which we have put forth not without witnesses, we shall be wondered at by people today and by those in the future. We do not at all need a Homer, nor anyone else, to praise us with verses which give pleasure for a moment, but whose interpretation of events will be destroyed by the truth.

${ }^{8}$ The association of thauma with Athens is something which very much differentiates Thucydides from Herodotus and his conception of the role and place of thauma in historiography, as Priestley (20I4) 64-6 points out. 


\subsection{The Wonder of Athens: Thucydides and Thauma}

Instead, we have forced every sea and every land open with our daring, and have established everywhere eternal monuments of our vengeance and our benefactions.

At this point in his oration, Pericles substantiates his earlier claim that Athens is an 'educational example to the whole of Greece' ( $\tau \tilde{\eta} S^{~ ' E} \lambda \lambda \alpha \dot{\delta} \delta \sigma^{\prime} \pi \alpha i \delta \varepsilon \cup \sigma i v, 2.4 \mathrm{I} . \mathrm{I}$ ) by confirming that the reports of her greatness which have so far circulated have not been exaggerated. The now clichéd claim that hearsay leads to false and misleading statements relating to marvels in far-off lands is firmly turned on its head, as Pericles paradoxically claims that in Athens' case, the reality is more astonishing than rumour. Even when put to the test, which in this case seems to imply the autoptic witnessing of great monuments or proofs of great deeds relating to Athenian power, Athens will remain marvellous. ${ }^{39}$

The wondrous reality of Athens is linked to her empire, mentioned explicitly here for the first and only time in the Funeral Oration, in Pericles' claim that those subjected to Athenian hegemony can bear no grudges in the face of such conspicuous strength and worthiness, and even her enemies cannot complain about being beaten by such a power. The present and future wonder inspired by the visible indications of this power is reminiscent of the present and future kleos which a god-crafted object, Achilles' shield, is able to provide to the individual warrior in the Iliad through the past and future wonder of many men..$^{40}$ But in this case a poet, even a Homer, is not needed to ensure the present and future fame of Athens: the obvious signs and memories of the city's marvellous power at home and abroad will ensure that of their own accord. This power now stretches over every land and sea, with the result that the mysterious and potentially wondrous nature of far-off lands is no longer a geographical certainty, seeing

39 Cf. also the fleeting reference to the wondrous nature of Athens just before Pericles' statement here, when he claims that the Lacedaemonians are inferior to the Athenians because they have to cultivate their courageous and manly behaviour by training themselves intensely from a young age, whereas the Athenians do not need to undergo such training because they are born this way. The city is thus worthy to be wondered at for these reasons, as well as those which Pericles will elaborate in the rest of the speech

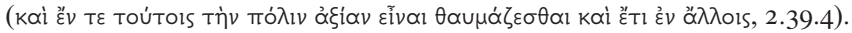

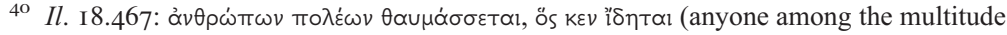
of men will marvel at it [i.e. the shield], whoever sees it). 
as Athens herself is now the natural domain of thaumata. Furthermore, Homer, and the mythical marvels which the sort of poetry he created contain, are no longer needed.

But there have already been hints in Thucydides' previous narrative that the potentially distorting and falsifying effects which Pericles claims Homer and the poets produce might also be created by Pericles' own speech. Although he claims that the mighty and wonder-inducing monuments of Athens attest to the power of the polis, we have already been warned early on in book I that the physical remains of the city are a misleading standard by which to judge Athens' power (I.IO.2-3):

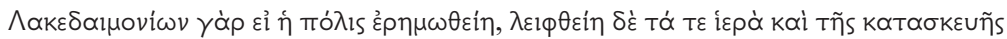

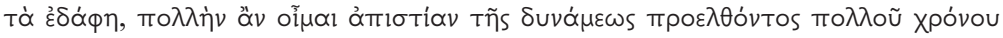

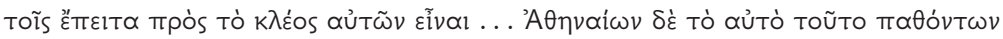

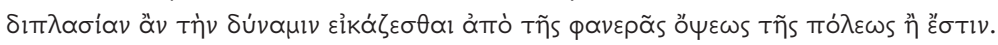

For if the city of the Lacedaemonians was abandoned, and only the temples and the traces of the infrastructure remained, I think that after a great length of time had passed people in the future would be in complete disbelief that their power matched their renown ... But if the same thing befell the Athenians their power would seem double what it is in reality from the visible remains of the city.

This retrospective view of the inequalities between the most obvious visible traces of Athenian and Lacedaemonian power colours Pericles' claims about Athens' capacity to inspire wonder through great monuments and achievements which bear witness to her greatness. Personal autopsy may be held up as a superior means of forming epistemological judgements, but appearances can, of course, be deceiving.

In fact, as Thucydides' narrative goes on to reveal, the visual manifestations of Athenian power in which Pericles places such trust turn out to guarantee nothing of the sort. Thauma, however, is a crucial means by which this sort of optical illusion occurs. As wonder takes over, the potential for misjudgements and miscalculations of magnitude increases. Funeral speeches (epitaphioi $\log$ i), such as the one delivered by Pericles, naturally overmagnify the objects of their praise, with speakers painting verbal pictures of the city and her people which aim at the glorification and memorialisation of the community and its past and present 
citizens above all else. We find a humorous yet telling critique of the potential dangers which this sort of intense focus on the city's marvellous nature might produce in Plato's Menexenus. Before embarking on his own version of an epitaphios logos, Socrates describes how such speeches change his visual and mental perceptions of the city, and even of himself $(235 \mathrm{a}-\mathrm{b})$ :

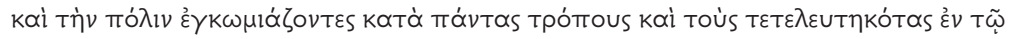

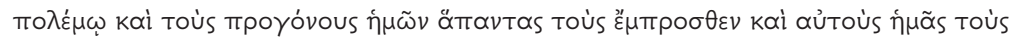

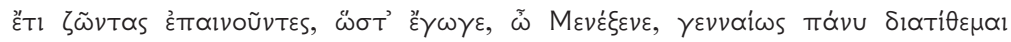

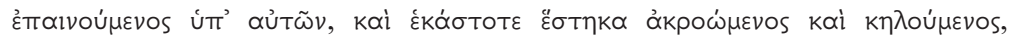

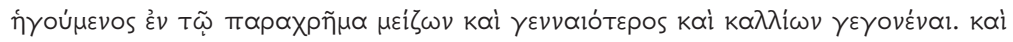

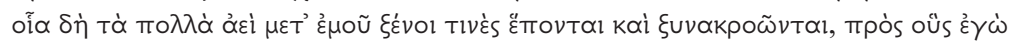

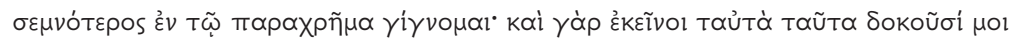

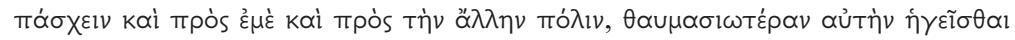

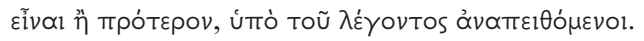

And they [i.e. the speakers of the epitaphioi logoi] extol the city in every possible way, praising both those who died in the war and our ancestors before us and ourselves, who are still living. As a result of this, Menexenus, I end up thinking of myself as extremely noble when I am praised by them. And each time, listening to them and being enchanted, I am raised up: right there on the spot I think I am bigger and nobler and handsomer. And often some foreign visitors tag along with me and listen: right there on the spot I become more awe-inspiring to them. For they seem to me to be affected in just the same way as I am with respect to me and the rest of the city, believing her to be more wonderful than before after being seduced by the speaker.

Socrates picks up on the potentially skewed effect which the verbal images crafted by orators have the power to create by claiming that he feels his own physical proportions increase as he listens to the praise of the city and its citizens, describing precisely the kind of distortion which the creation of thauma is able to induce. Although Socrates is obviously exaggerating here, this humorous portrayal of the effects of epitaphioi logoi nevertheless contains a more serious critique of the conceptual illusions which wonder-inducing language may help to encourage..$^{4 \mathrm{I}}$ It is this aspect of the power of thauma that Thucydides also engages

4I On the dangerous effects of the rhetoric of the epitaphios logos which Plato outlines in the Menexenus' prologue, and on the place of thauma in this passage, see Loraux (I986) $264-70$. 
with in his portrayal of Pericles' wonderful vision of Athens in his own Funeral Oration.

But it is only as Thucydides' account of the Peloponnesian War progresses that the risk of unreflectively falling prey to the distorting power of thauma truly becomes apparent. One of the ways in which the danger of thauma is demonstrated is through the increasing importance of the idea of skewed and distorted perceptions over the course of the narrative of the expedition to Sicily. In connection with this, we find that the antithesis between the near and the far is continually turned on its head over the course of books 6 and 7. Just as Euripides' Ion demonstrates the risk of simultaneously wondering at and fearing potential threats from far-off when it is matters close at hand which constitute true hazards, the dangers which might be thought to lurk in the west at the beginning of the narrative of the Sicilian expedition actually turn out to be situated at home, with mistakes in Athens ultimately leading to disaster abroad. ${ }^{42}$

Before the expedition even sets sail, the ability of wonder to skew perceptions is explored by Nicias in his first speech. Nicias cautions the Athenians to use their capacity to inspire wonder wisely, arguing that the idea of wondrous power far-off is more awe-inspiring than the reality of thaumata close up once they are put to the test (6.I I.4):

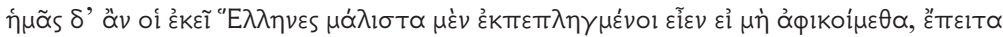

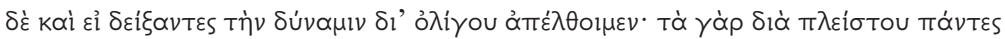

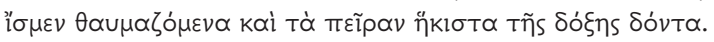

But the Hellenes there would be especially astonished if we did not turn up at all; second best would be to depart after making a display of our power for a short time. For we all know that the things which are furthest off and which give the least opportunity to put their reputation to the test are wondered at.

These words echo those of Pericles' Funeral Oration on the subject of thauma. While Pericles claims that the wonder-inspiring aspects of Athens can be put to the test and not found wanting, Nicias suggests that thaumata can lose their power by becoming

42 See Rood (I998) I33-82 on the connections between mistakes at home and results abroad in the Sicilian narrative; cf. Taylor (20I0) I35-87 on the frequent inversion of what is near/far within the narrative of the Sicilian expedition. 
familiar when seen close up. In contrast to Pericles' view that Athens alone can withstand intense scrutiny at close quarters and remain impressive, Nicias grasps the fact that it is through distance that the potentially thaumatic power of Athens retains its mystique in the eyes of others.

What Nicias does not grasp, however, is the fact that it is this same alluring fascination with the distant which enthuses the Athenians in the build-up to the Sicilian expedition. He may be correct in his contention that 'the things furthest off are wondered at and give the least opportunity to put their reputation to the test', but he does not take account of the fact that this inability to put matters to the test can also increase desire, if the imagination is gripped by a longing for thaumata rather than a fear of the unknown. In fact, Nicias' constant reminders (and exaggerations) of the extreme distance of Sicily only inflame Athenian desire for the acquisition of potentially marvellous far-off lands, rather than dissuading the polis from the difficult enterprise which has been proposed. Nicias seems aware that longing for the distant is a risk in his first speech when he appeals to the older citizens to not be seized by 'a harmful desire for things far away'

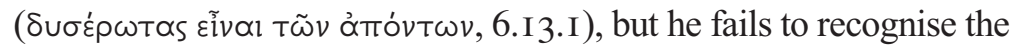
danger his own rhetoric creates, as it repeatedly places the idea of Sicily as a distant land into the minds of his listeners. Ironically, and quite inadvertently, these words create a marvellous distorting effect of their own. Although Nicias expects that his speech will either dissuade the Athenians from the expedition, or at least make them more cautious about it because of 'the great number of issues' ( $\tau \tilde{\omega}$ $\pi \lambda \dot{\theta} \theta \varepsilon 1 \tau \tilde{\omega} \nu \pi \rho \alpha \gamma \mu \alpha \dot{\tau} \tau \omega \nu, 6.24$.I) he has taken pains to outline, his words have the very opposite effect, with the result that 'those

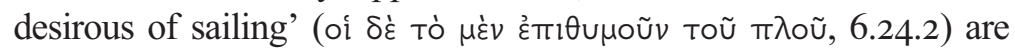
only encouraged by his speech rather than deterred. Nicias even misjudges the effect of his words on the older Athenian citizens whom he expects to side with him against the youthful impetuousness of Alcibiades and his followers. In fact, his rhetoric only serves to remind the polis of the wondrous potential of Athenian martial glory and achievements like those described in Pericles' Funeral Oration, with the result that these warnings inflame the desire (eros) for conquest of both young and old alike (6.24.3): 


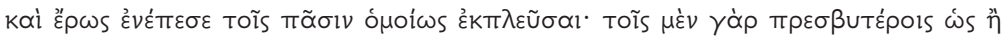

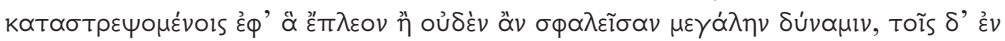

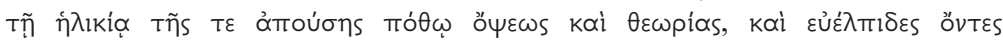
$\sigma \omega \theta \dot{\sigma} \sigma \varepsilon \sigma \theta \propto$.

And a passionate desire to set sail gripped everyone equally: the elder men believed that either they would trample upon the places they were sailing against, or that the great force would suffer no disaster, while a longing for far-off spectacles and sights fell upon the younger men, and they were all extremely confident that they would be alright.

Despite Nicias' warnings against the potentially damaging effects of harmful desire, his warning again increases the Athenians' daring and desperate desire for the possession of far-off lands and the attainment of unknown glory.

The language of longing for the far-off here is reminiscent of the sentiment expressed in Pindar's Pythian 3, which describes Coronis' punishment because 'she was in love with things far-

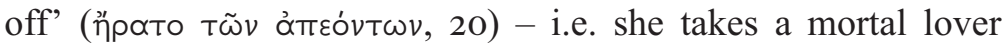
despite the fact that she is already pregnant with Apollo's child Asclepius. As a result of this, Coronis becomes one of the many foolish people 'who despise what is near at hand and set their

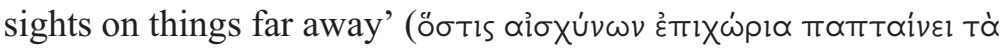

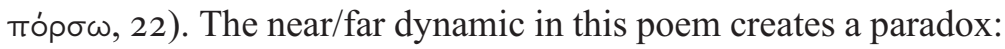
a mortal lover should be much closer to the mortal Coronis than a god, but in this instance her longing for what should be much more familiar to her has become strangely transgressive after Apollo's previous attentions. The Athenian situation in Thucydides presents a similar sort of paradox: on the one hand, the Syracusans are continually presented as exotic, distant and desirable, yet as books 6 and 7 progress it becomes clear that the Athenians and Syracusans are actually now very similar to each other in many ways. It is this paradoxical longing for something unfamiliar yet familiar which causes disaster for the Athenians, just as it does for Coronis in Pindar's poem. ${ }^{43}$

Even more paradoxically, this increased longing for far-off sights is further inflamed by the astonishing spectacles of

43 On the near/far theme in Pyth. 3, see Young (I968) 27-68; on the closeness of Thucydides' language to this Pindaric parallel, see Cornford (I907) 206, Rood (I998)

I 77 n. 68, Hornblower (2004) 73 and (2008) 335. 
Athenian power at home, which Thucydides suggests distort Athenian conceptions of the true strength of their hegemony. It is through the figure of Alcibiades that we gain an increasing awareness of the nature of these types of distortion. After warning the Athenians about the dangers of diluting their capacity for inspiring wonder by making themselves overfamiliar to the enemy, Nicias turns to the danger that Alcibiades poses to the polis. He condemns the younger man for considering only his own interest while exhorting the Athenians to sail, and for thinking about how he might profit from the expedition and be 'wondered at for his habit

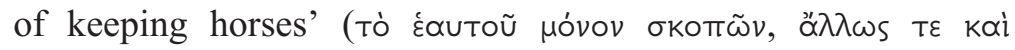

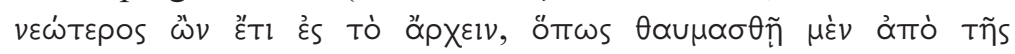

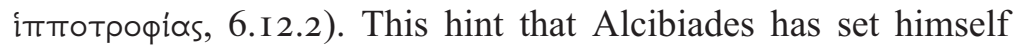
up as a distracting object of wonder to the Athenians is soon confirmed by the younger man's reply to Nicias. Rather than refuting his criticism, Alcibiades instead embraces the suggestion that his life and conduct are an impressive and marvellous sight to behold, and suggests that this approach to his personal life has already yielded results for the polis. Nicias may have disparaged the way in which he has set himself up as an object of wonder because of his love of horses, but Alcibiades retorts (6.I6.2) that the rest of the Hellenes now think that Athenian power is even greater than it really is as a result of his decision to enter seven chariots into the races at Olympia. He goes on (6.I6.3) to claim that his other displays of wealth and brilliance in the city also produce an impression of strength in the eyes of foreigners, even if fellow citizens become jealous as a result. The brilliant, wonderinducing exterior appearance of power is here confused with power itself, as Alcibiades concentrates on the external appearance and trappings of command throughout his speech. ${ }^{44}$

It is this sense of wonder, and its distorting effects, which Thucydides goes on to suggest are one of the causes of the subsequent negative outcome in Sicily, and nowhere is the potential confusion between the trappings of power and power itself more apparent than in the fleet's embarkation from Athens at

44 On the focus on appearances in Alcibiades' speech and its distinction from the reality of the situation, see Macleod (I983) 86 and Jordan (2000) 70-I. 
6.30-I. ${ }^{45}$ Like Alcibiades' conspicuous display at Olympia, the Athenian fleet itself is 'a spectacle' ( $\theta \dot{\varepsilon} \alpha v, 6.3$ I.I), and its embarkation 'more resembled a display of power and wealth aimed at all the other Hellenes than an expedition against enemies' ( $\dot{\varepsilon} \varsigma$ toùs

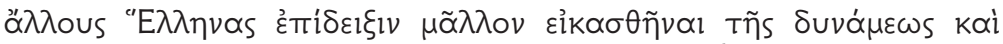

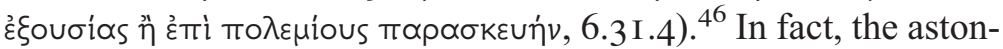
ishment caused by the sight of the Athenians setting off echoes, on a broader civic level, the external brilliance of the sight of Alcibiades' lifestyle (6.3 I.6):

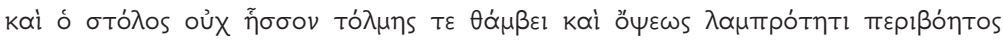

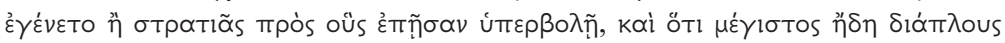

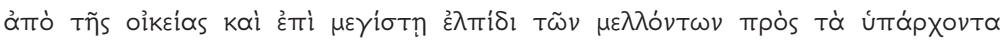

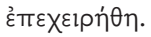

And the expedition became no less famous for astonishment at its boldness and the brilliance of its spectacle, than for the disproportionate strength of the force compared to those whom it was directed against, and also because it was the lengthiest voyage away from home yet attempted and there was such great hope for the future in relation to their present resources.

The powerful astonishment (thambos) which the fleet inspires here is misplaced, aimed at those in Athens watching the spectacle, rather than at the enemy, as Nicias previously advised. Thucydides portrays the effects of this misplaced sense of astonishment as disastrous: by wondering at the sight of power close to home, it now becomes impossible to judge the true capabilities of Athenian influence abroad.

An important aspect of this misjudgement turns out to be the inability to appreciate how close, rather than distant, the military capabilities of Syracuse and the other Sicilian cities are to those of the Athenians. Although Nicias seems to grasp this and warn his fellow citizens that the Sicilian cities are 'equipped with everything in a manner very similar to our force' ( $\pi \alpha \rho \varepsilon \sigma k \varepsilon \cup \alpha \sigma \mu \varepsilon \dot{v} \alpha$ l тоĩ

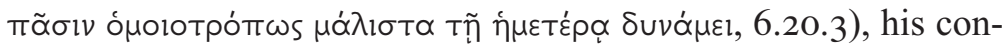
stant talk of the geographical distance of Sicily from Athens

45 Cf. Jordan (2000) 63-79 and Kallet (200I) 2I-84 on the specious nature of Athenian power which the spectacle of embarkation exposes.

46 On the connection between the astonishment inspired by the appearance of Alcibiades' wondrous lifestyle and the spectacle of the Athenian fleet setting sail, see Jordan (2000) 65 and Kallet (200I) 64 . 


\subsection{The Wonder of Athens: Thucydides and Thauma}

perhaps dilutes this aspect of his message, encouraging his fellow Athenians to confuse spatial distance with cultural difference by inadvertently exoticising the distant regions to the west. Only in book 7, at the point when it has become clear to the Athenians that the expedition is a disastrous miscalculation, does the reality of Syracusan similarity become apparent to the attackers: the Sicilian cities are the only places the Athenians have encountered which are 'similar in manner' (óногтро́то1s, 7.55.2) to their own city in terms of their culture and democratic way of life - as well as being

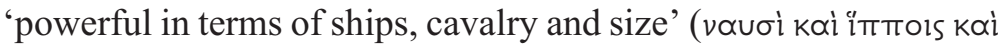

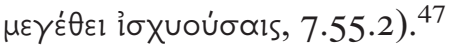

In fact, uncanny similarities between the two powers continue to arise as Syracuse takes on the mantle of Athens in the Persian Wars, becoming a brave and free city resisting the Athenians' increasingly tyrannical (and Persian-looking) imperialistic overreach. ${ }^{48}$ The sense of paradoxical similarity and simultaneous reversal is complete when the Syracusans, encouraged by their growing military success, resolve to continue to press their advantage over the Athenians until they have utterly destroyed them on land and on sea to ensure that they are "wondered at by everyone at

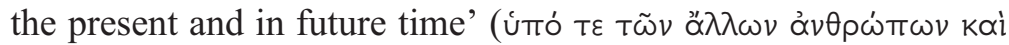

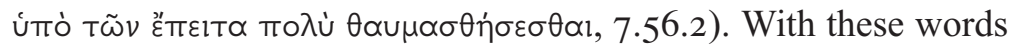
the ironic reversal of the sentiment of Pericles' Funeral Oration (2.4I.3-4), which set up the image of Athens as the ultimate thauma, is now almost complete. This reversal is made fully clear when Nicias, before the final battle in the harbour, exhorts his dispirited sailors to continue fighting hard and praises the fleet's metic sailors, rather than Athenian citizens, for being 'won-

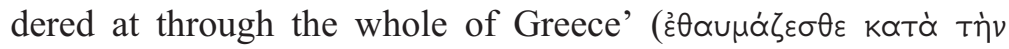
'E $\mathrm{\lambda} \lambda \alpha \dot{\alpha} \delta \alpha, 7.63 .3$ ) as a result of learning the Athenians' language and way of life. Again, the Athenians' notions of near and far have been skewed in relation to the effects of thauma, as non-native

47 See Rood (I999) I62 and Hornblower (2008) 2 I-2 on the similarities and parallels Thucydides draws between the Athenians and Syracusans as the Sicilian narrative progresses.

48 On the similarity of Athens' imperial ambitions in the History to those of Persia against Greece in Herodotus, see Rood (I998) I 97 and (I 999) I4 I-68, Cornford (I 907) 20 I-20 and Rogkotis (2006) 57-86. 
metics are now objects of wonder through their association with Athens, and might even now be seen as objects of competitive emulation for the dejected citizens of Athens themselves. ${ }^{49}$ From this point on, Athens and her native Athenian citizens are no longer able to inspire thauma. The confident and admiring (yet ultimately deceptive) thauma and thambos which the Athenian fleet attracted as it set sail on this expedition is replaced instead with a different type of astonishment: panicked and disbelieving ekplexis twice grips the Athenians (7.70.6 and 7.7I.7) as they contemplate the battle and its disastrous effects and recognise the true status of their power away from home. ${ }^{50}$

The vision of Athens which Pericles' Funeral Oration paints in words does not stand up to scrutiny in the long run after all. In both Aristophanes' Birds and Thucydides' History, wonder is now one of the most powerful envisaged effects of the images which the successful rhetorician is able to plant in the minds of his audience. In both of these authors, we can see that there has been a marked change in the way in which the power and effect of thauma is conceptualised over the course of the Classical period. Objects which provoke thauma are no longer presented as potentially disconcerting because of the strangeness and otherness caused either by their association with the divine realm, or with unfamiliar peoples and locations. Nor is thauma used to describe the positive effects of shared experiences between mortals and gods. Instead, an encounter with thauma is often imbued with increasingly negative overtones of deception and trickery. Wondrous experiences may be both desirable and enjoyable, but they are also potentially misleading, even dangerous on occasion. Thauma has

49 There are further echoes of Pericles' Funeral Oration here at 7.63.3 as well: see Rood (I998) I93; cf. also Joho (2017) I6-48 on the echoes and reversals of Pericles' Funeral Oration in books 6 and 7 more generally.

50 See Jordan (2000) 77 on the transformation of the wonder inspired by Alcibiades and the sight of the fleet setting sail in book 6 into the shocked and panicked ekplexis of book 7 . Cf. Hunter (I986) $4 \mathrm{I} 8$ on the importance of ekplexis in conveying the scale of the Athenian reversal in book 7, and Allison (I997) 62-5 on the particular association of ekplexis with the Sicilian expedition. Cf. also the ironic reversal of the earlier misguided ekplexis of the Athenian envoys at the deceptive sight of the Egestans' supposed wealth

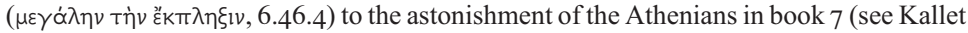
(200I) 78 on this reversal), and Rogkotis (2006) 68-9 on the verbal analogies between the Egestan deception at 6.46 and the astonishing spectacle of the fleet's departure. 
6.3 The Wonder of Athens: Thucydides and Thauma

become associated with the act of representation itself, with the arousal of a marvelling response now a means of inverting (and often subverting) an audience's conventional perspectives on their most familiar surroundings and beliefs. ${ }^{5 \mathrm{I}}$ It is a powerful effect of mimetic acts of representation which somehow involve the defamiliarisation and refamiliarisation of reality, especially through the use of rhetoric, which often distorts language for its own ends. It is this notion of the potential power of thauma which the next chapter will explore in further depth.

5I A crucial aspect of the potentially radical effect of thauma which is rightly noted by D'Angour (20II) I49: 'Even if an object of wonder is familiar, the experience of thauma may create a new perspective which transports the observer into new realms of emotion, thought or feeling.' 